\title{
Comparative activity of pulsed or continuous estradiol exposure on gene expression and proliferation of normal and tumoral human breast cells
}

\author{
V Cavaillès, A Gompel ${ }^{1}$, M C Portois ${ }^{1}$, S Thénot, N Mabon ${ }^{2}$ and F Vignon \\ Inserm Unit 540, Molecular and Cellular Endocrinology of Cancers, 60 rue de Navacelles, 34090 Montpellier, France \\ ${ }^{1}$ Department of Gynecology, Assistance Publique-Hôpitaux de Paris, Hôtel Dieu Hospital and Inserm Unit 339, Cellular Imaging of Neuroreceptors and \\ Neuroendocrine Pathology, Saint-Antoine Hospital, Paris, France \\ ${ }^{2}$ Unit of Endocrinology and Rheumatology, Institut de Recherches Internationales Servier, Courbevoie, France
}

(Requests for offprints should be addressed to F Vignon; Email: vignon@u540.montp.inserm.fr)

\begin{abstract}
Intranasal administration of hormone replacement therapy presents an original plasma kinetic profile with transient estrogen levels giving rise to the concept of pulsed therapy. To further understand the molecular effects of this new therapy, we have compared the effects of pulsed and continuous estradiol treatments on two critical aspects of estradiol action: gene expression and cell proliferation. Cells were stimulated with estradiol as 1-h pulsed or 24-h continuous treatments at concentrations such that the 24-h exposure (concentration $\times$ time) was identical in both conditions. In MCF7 cells, the transcriptional activity of estrogen receptors (ER) on a transiently transfected responsive estrogen response element-luciferase reporter construct was shown to be drastically $(\sim 10$-fold $)$ and similarly stimulated after both treatments. Moreover, the increased mRNA expression of three representative estradiol-sensitive genes ( $\mathrm{pS}$, cathepsin D, progesterone receptor), evaluated by Northern blot, was identical after 1-h pulse with $7 \mathrm{nM}$ estradiol or continuous treatment with $0.29 \mathrm{nM}$ estradiol with the same kinetic profile over $48 \mathrm{~h}$. Proliferation was quantified by a histomorphometric method on primary cultures of human normal breast cells from reduction mammoplasties and using a fluorescence DNA assay in six human breast cancer cell lines which were ER positive or negative. After a 7-day treatment period, estradiol had no effect on the proliferation of the three ER negative cell lines (BT20, MDA MB231, SK BR3) but significantly stimulated the proliferation of the normal cells and of the three tumoral hormone-sensitive cell lines (MCF7, T47D, ZR 75-1); both hormone treatments producing the same increases in cell growth. In conclusion, we have shown that the genomic or proliferative effects of estradiol were identical with pulsed or continuous treatments, thus indicating that estrogenic effects are not strictly related to concentrations but rather to total hormone exposure.
\end{abstract}

Journal of Molecular Endocrinology (2002) 28, 165-175

\section{Introduction}

Aerodiol (Servier Laboratories, Neuilly-sur-Seine, France) is a novel formulation of $17 \beta$-estradiol intended to be administered by the nasal route for estrogen replacement therapy, in particular during the menopause. The nasal route offers many advantages when compared with the oral route since it circumvents major estradiol intestinal and hepatic first pass effects (Hussain 1998) and their adverse repercussions (Lievertz 1987); moreover, the nasal mucosa has been proven to be a good absorption site for estradiol and several other steroid hormones. Comparative clinical and pharmacokinetic studies performed with reference products and conducted in postmenopausal women have demonstrated that nasal administration of Aerodiol at a dose of $300 \mu \mathrm{g}$ estradiol resulted in the same efficacy on climacteric symptoms as oral estradiol at a dose of $2 \mathrm{mg}$ (Studd et al. 1999) and transdermal as estradiol at a dose of $50 \mu \mathrm{g} /$ day (Lopes et al. 2000); at these doses nasal, oral and transdermal formulations have close 24-h hormonal impregnation (Devissaguet et al. 1999). 
However, the kinetic profile of Aerodiol is completely different and introduced the concept of pulsed estrogen therapy: plasma estradiol concentrations reach transient high levels 10-30 min after administration, and return to postmenopausal values within 6 to $12 \mathrm{~h}$. By contrast, transdermal and oral formulations lead to lower sustained estradiol concentrations over $24 \mathrm{~h}$.

$17 \beta$-Estradiol is known to produce its major long-term effects on cell structure and functions via its nuclear receptors $(\mathrm{ER} \alpha$ and $\beta)$ which regulate gene transcription and elicit specific protein synthesis (Gronemeyer \& Laudet 1995). Binding of the ligand to ER triggers a cascade of events which end up with the modulation of gene expression reflected by changes in some specific mRNAs and protein synthesis as well as pleiotropic effects on cell proliferation. Our first goal was to demonstrate that pulsed exposures were as efficient as continuous exposures on the expression of endogenous or transfected estrogen-regulated genes. Moreover, since the role of estrogens in the promotion of mammary or endometrial tumors is well known (IARG 1999), it was important to show that the presence of such transient levels of estradiol after nasal treatment did not elicit unexpected biological effects different from those encountered with lower but steady levels as observed with orally administered hormone. Cell proliferation having been described as the most important receptor-mediated mechanism by which hormonally active compounds act in carcinogenesis of hormone-sensitive target tissues (IARG 1999), the second part of the present study was devised to evaluate the in vitro proliferation of normal or tumoral human breast cells. The experimental conditions of estradiol exposure mimicked those observed in vivo in humans when estradiol is administered nasally and orally. Our results have demonstrated that genomic or proliferative effects of estradiol are not strictly related to concentrations of estradiol but rather to total exposure.

\section{Materials and Methods}

\section{Human breast cancer cell lines}

Human breast cancer cell lines were either obtained from the American Type Culture Collection (Rockville, MD, USA) (SK BR3, BT20), the Mason Research Institute (Rockville, MD,
USA) (MDA MB231), the Michigan Cancer Foundation (Detroit, MI, USA) (MCF7) or were donated by Dr Keydar (Tel Aviv, Israel) (T47D) or Dr Lippman (NIH-NCI, Bethesda, MD, USA) (ZR 75-1). They were maintained under routine conditions $\left(37^{\circ} \mathrm{C}, 5 \% \mathrm{CO}_{2}\right)$ in their respective culture media (RPMI 1640 medium for T47D, BT20 and SK BR3; a 1/1 mixture of Ham's F12 (F12) and Dulbecco's modified Eagle's medium (DEM) (F12/DEM) for MCF7 and ZR 75-1; DEM for MDA MB231 supplemented with 10\% fetal calf serum (FCS) and penicillin/streptomycin (50 $\mathrm{U} / \mathrm{ml}-50 \mu \mathrm{g} / \mathrm{ml}$ ) (Life-Technologies, Rockford, $\mathrm{MD}, \mathrm{USA})$ ).

\section{Normal human breast epithelial (HBE) cells}

Normal breast samples from 15 young women aged less than 25 years, without breast disease, who were undergoing reduction mammoplasty for esthetic purposes, were collected, according to the French law on clinical experimentation. They were digested with collagenase $(0 \cdot 15 \%$; Boehringer Mannheim Chemical, Mannheim, Germany) plus hyaluronidase (0.05\%; Sigma, St Louis, MO, USA) in Ham's F10 medium (Life-Technologies) and filtered through sieves to obtain pure normal epithelial cells (Prudhomme et al. 1984). These cells were then allowed to grow at $37^{\circ} \mathrm{C}$ until subconfluence in a Ham's F10 medium containing insulin $(0 \cdot 12 \mathrm{U} / \mathrm{ml})$, epidermal growth factor $(\mathrm{EGF} ; 10 \mathrm{ng} / \mathrm{ml})$, cholera toxin $(10 \mathrm{ng} / \mathrm{ml})$, triiodothyronine $(6.5 \mathrm{ng} / \mathrm{ml})$, cortisol $(5 \mathrm{ng} / \mathrm{ml}$ ) (all obtained from Sigma) and 5\% human serum (medium A).

\section{Estrogen solutions}

Solutions of estradiol hemihydrate (batch 45302 provided by IRIS, Paris, France) and estrone (E9750; Sigma) were prepared in absolute ethanol and stored at $4{ }^{\circ} \mathrm{C}$ in brown glass vials until use.

\section{Transient transfection and luciferase assay}

To withdraw endogenous steroids, MCF7 cells were washed twice with phosphate-buffered saline (PBS) or plain medium and then cultured for 5 days in phenol red-free medium supplemented with $5 \%$ dextran-coated charcoal treated FCS (DCG/FCS) (Vignon et al. 1980). MCF7 cells were seeded at 
$2 \times 10^{6}$ cells/well in 6-well dishes (Falcon, Oxnard, CA, USA) and transiently transfected the following day by the calcium-phosphate method as previously described (Thenot et al. 1999). Precipitates $(5 \mu \mathrm{g}$ DNA/well) contained $0.5 \mu \mathrm{g}$ of the $17 \mathrm{~EB}$ LUC+ reporter plasmid (Demirpence et al. 1992) with the consensus estrogen response element (ERE), upstream of the $\beta$-globin promoter and the luciferase reporter gene, $2 \mu \mathrm{g}$ of the control plasmid CMV- $\beta$-Gal (Clontech, Palo Alto, CA, USA) and $2.5 \mu \mathrm{g}$ carrier plasmid pSG5. The following morning, cells were washed twice with PBS and stimulated with estradiol either at a high dose $(7 \mathrm{nM})$ for $1 \mathrm{~h}$ or at a low dose $(0 \cdot 29 \mathrm{nM})$ for $24 \mathrm{~h}$. Whole cell extracts were then prepared 12, 24, 36 or $48 \mathrm{~h}$ later in a cell lysis buffer (Promega, Madison, WI, USA). In a second series of experiments, a 1-h pulsed and a 24-h sustained treatment were performed and repeated the next day for an assessment of gene expression at $48 \mathrm{~h}$. Luciferase activity was measured using an LKB 1251 luminometer by injection of luciferase assay reagent (Promega). $\beta$-Galactosidase $(\beta$-Gal) activity was evaluated using a $\beta$-Gal buffer $\left(\mathrm{MgCl}_{2} 1 \mathrm{mM}\right.$, $\beta$-mercaptoethanol $45 \mathrm{mM}$, orthonitrophenyl $\beta$-Dgalactopyranoside $4 \mathrm{mg} / \mathrm{ml}$ in $\mathrm{PBS}$ ). The reaction was stopped by adding $250 \mu \mathrm{l} \mathrm{Na} \mathrm{CO}_{3}(1 \mathrm{M})$ and optical density at $420 \mathrm{~nm}$ was measured. Luciferase activity is expressed as relative luciferase units after correction for transfection efficacy using the $\beta$-Gal values. Three different experiments were performed in triplicate and statistical analyses were performed by two-way ANOVA with contrast using BMDP software (Release 7) (Statistical Solutions Limited, Cork, Ireland) at the Biostatistics Laboratory (EA2415, by Professsor J P Daurès, University of Medicine, Montpellier, France). $P<0.05$ was considered as significant.

\section{Northern blot experiments}

MCF7 cells grown in $75 \mathrm{~cm}^{2}$ flasks (Falcon) were withdrawn from steroids for 5 days prior to stimulation by estradiol. Total RNA was isolated using TRIzol reagent according to the manufacturer's procedure. RNA samples $(40 \mu \mathrm{g})$ were loaded onto a $1 \%$ agarose denaturing gel and, after partial hydrolysis with $\mathrm{NaOH}$, transferred onto nylon membranes and immobilized by UV irradiation. Blots were prehybridized for $16 \mathrm{~h}$ at $42{ }^{\circ} \mathrm{C}$ and hybridized with the different ${ }^{32} \mathrm{P}$-labeled probes at $2 \times 10^{6}$ c.p.m. $/ \mathrm{ml}$ for 2 days at $42{ }^{\circ} \mathrm{C}$. Probes were labeled using the Megaprime DNA labeling system (Life Technologies), according to the manufacturer's conditions. Membranes were washed twice in $1 \times \mathrm{SSC}, 0 \cdot 1 \% \mathrm{SDS}$ for $1 \mathrm{~h}$ at $65{ }^{\circ} \mathrm{C}$ and exposed for $24 \mathrm{~h}$ in a phosphorimager cassette. Hybridizations were done first with progesterone receptor (PR) and cathepsin D probes, then with $36 \mathrm{~B} 4$ and pS2 probes. Plasmids containing cDNA sequences corresponding to 36B4, pS2 and cathepsin D (Cavailles et al. 1989) mRNAs were linearized. The PR probe corresponded to a fragment of $0.42 \mathrm{~kb}$ from the plasmid containing the B form of PR (Kastner et al. 1990). Values are expressed as photo-stimulated luminescence units and corrected using the estradiolinsensitive 36B4 mRNA levels. Three sets of experiments were performed and statistical analyses were as for transient transfection.

\section{Cell growth experiments and proliferation assays}

\section{Normal HBE cells}

For proliferation studies, the normal human breast cells were cultured for 2 days in $25 \mathrm{~cm}^{2}$ flasks and, following a 24-h deprivation of serum, treated with estradiol in medium B, identical to medium A apart from being deprived of phenol red and containing human serum $(1 \%)$, it also has EGF and insulin at concentrations $1 / 5$ compared with those of medium A. A minimal amount (1\%) of compatible human serum (Gompel et al. 1986) was used since DCG/FGS does not sustain HBE cell growth. This low concentration of serum provides the medium with estrogen concentrations below $10^{-11} \mathrm{M}$ which therefore do not interfere with estradiol treatment. Cells were treated every 2 days with a pulse of $24 \mathrm{nM}$ estradiol for $1 \mathrm{~h}$ or with continuous $1 \mathrm{nM}$ estradiol for 1 week. Control cells treated with $0 \cdot 1 \%$ ethanol were also run in parallel. After $1-\mathrm{h}$ estradiol pulsed incubation, cells were washed and fresh medium was added (Ham's F10 without phenol red and $1 \%$ final serum concentration). Daily quantification of the proliferation was carried out using a validated morphometric method (Gompel et al. 1986). The numbers of intersections of a micrometric grid falling on cells were counted on seven fields every day. Proliferation is expressed as a histomorphometric growth index (HGI) and results are given as its percentage increase 
(means \pm S.E.M.) from the first day, calculated as $\mathrm{HGI}=\mathrm{D} n-\mathrm{D} 1 / \mathrm{D} 1$ (where $\mathrm{D}=$ day, $n=1,2$ etc). Five separate experiments in triplicate were conducted and statistical analysis was performed using F-test and Neuman-Keuls analysis. $P<0.05$ was considered as significant.

To study estrogen intracellular retention (Prudhomme et al. 1984), cells cultured as above were treated with $24 \mathrm{nM}\left[{ }^{3} \mathrm{H}\right]$ estradiol ([6,7$\left.{ }^{3} \mathrm{H}\right]$ estradiol, specific activity $53 \mathrm{Ci} / \mathrm{mmol}$; NEN Research Products, Boston, MA, USA) for $1 \mathrm{~h}$ and harvested at $10 \mathrm{~min}, 30 \mathrm{~min}, 1 \mathrm{~h}, 2 \mathrm{~h}, 8 \mathrm{~h}$ and $24 \mathrm{~h}$ following hormone addition. After centrifugation, radioactivity was extracted from the pellet using three washes in ethanol containing $\left[4-{ }^{14} \mathrm{C}\right]$ estradiol and $\left[4-{ }^{14} \mathrm{C}\right]$ estrone $(3000$ d.p.m. each, specific activity, $57 \mathrm{mCi} / \mathrm{mmol}$; NEN Research Products) to monitor recovery. Thin layer chromatography was carried out on silicagel with a cyclohexaneethyl acetate $(\mathrm{v} / \mathrm{v})$ separation phase. Estradiol and estrone were measured at each time of estradiol incubation. Losses were estimated from the recovery of the ${ }^{14} \mathrm{C}$-labeled tracers added to the samples. All experiments were performed in triplicate. DNA was quantified according to the 4',6-diamidino-2-phenylindol method using a fluorimeter. The results are expressed as fmol/ $\mu \mathrm{g}$ DNA.

\section{Human breast cancer cell lines}

For growth experiments, cells were cultured in steroid-free media containing 10\% DCG/FCS for 2 days and then switched to 3\% DCG/FGS media for 3 days prior to plating in 24-well dishes (Falcon). Cells in dishes were left unchanged in 3\% DCG/FCS media for 3 more days and then stimulated in media containing 3\% (BT20, MDA MB231, SK BR3, ZR 75-1 and T47D) or $1 \%$ (MCF7) DCG/FCS with increasing concentrations of estradiol. For pulsed treatment, cells were stimulated with estradiol for $1 \mathrm{~h}$ every day and returned to the control medium for the remaining $23 \mathrm{~h}$ (medium with ethanol and 3 or $1 \%$ DCG/FCS). For continuous daily treatments, cells were incubated for $24 \mathrm{~h}$ with media containing estradiol following the same scheme of media changes. Growth was evaluated after 7 days of 1 -h and 24-h daily treatment by total DNA measurement on three replicate wells fixed in situ with methanol by the DABA fluorimetric assay $405 \mathrm{~nm}$ excitation; $495 \mathrm{~nm}$ emission), as previously vali-
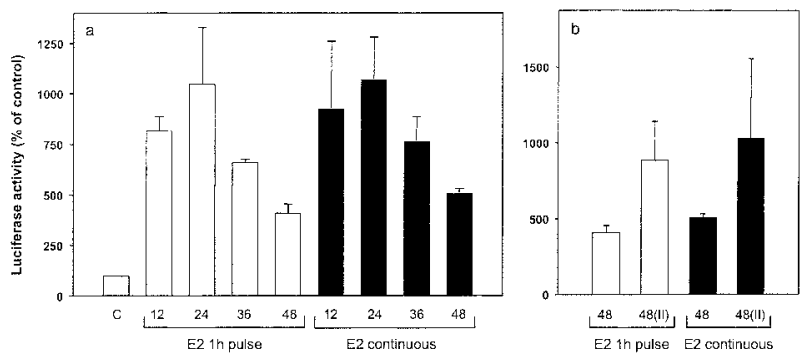

Figure 1 Effect of estradiol (E2) on the expression of a transfected reporter gene. MCF7 human breast cancer cells were transiently transfected as described in Materials and Methods. (a) Luciferase activity from the 17EBLUC construct was monitored 12, 24, 36 and $48 \mathrm{~h}$ after a single 1-h pulsed stimulation at $7 \mathrm{nM}$ (open bars) or 24-h continuous treatment at $0.29 \mathrm{nM}$ (solid bars). For each treatment, basal levels (C; grey bar) were measured in control cells treated with solvent alone. (b) Luciferase activity was also monitored $48 \mathrm{~h}$ after the beginning of a 1-h pulsed (open bars) or 24-h continuous treatment (solid bars) performed for 2 successive days (48(II)). Luciferase activity is expressed as $\%$ of control cells and included three independent experiments with each condition in triplicate. Values are means \pm S.D.

dated (Vignon et al. 1992). Results are expressed in $\mu \mathrm{g}$ DNA by reference to a standard calf thymus DNA curve and then individually converted in percentage values versus control wells. Each final result represents the mean \pm S.D. of three separate experiments run in triplicate and statistical analyses were as for transient transfections.

\section{Results}

\section{Gene expression using a transfected reporter plasmid containing an ERE}

The study of the regulation of ER transcriptional activity using transient transfection with an ERE reporter construct was our first approach to compare pulsed and continuous estrogen treatment efficacy at concentrations chosen to reflect those found in the plasma of postmenopausal women under hormone replacement therapy in both cases (Devissaguet et al. 1999). Whether estradiol was administered as a 24-h continuous treatment at $0.29 \mathrm{nM}$ concentration or as a 1-h pulsed stimulation at $7 \mathrm{nM}$ concentration, it resulted in a drastic increase in luciferase activity over controls (5- to 11-fold range) (Fig. 1). This increase was not significantly different between the pulsed or 
continuous single stimulation whatever the time of measurement after the beginning of treatment (Fig. la); it reached a maximum at $24 \mathrm{~h}$ which varied when compared with controls from $8 \cdot 7$ - to $14 \cdot 7$-fold for the continuous treatment (mean $\sim 10$-fold) and from $7 \cdot 6$ - to $15 \cdot 1$-fold for the pulsed treatment (mean $\sim 10$-fold) between experiments (not shown) and decreased from then on gradually to attain a mean $4 \cdot 5$-fold stimulation at $48 \mathrm{~h}$. When treatments were repeated on 2 successive days (Fig. 1b), no statistical difference in the effect of pulsed or continuous treatments was found $48 \mathrm{~h}$ after the beginning of the exposure to estradiol and the extent of the effect was in the same range of values to those observed $24 \mathrm{~h}$ after a single exposure (Fig. 1).

\section{mRNA expression of three endogenous genes}

Using Northern blotting experiment and quantification, we then compared the effects of the two modes of estradiol treatment on the mRNA expression levels of three endogenous hormoneregulated genes which are the most frequently studied in breast cancer cells, the PR, the pS2 protein and the lysosomal protease cathepsin D (Rochefort 1995) (Fig. 2a). All three mRNAs levels were significantly increased by either a continuous 24-h estradiol treatment at $0.29 \mathrm{nM}$ or a 1 -h pulsed estradiol stimulation at $7 \mathrm{nM}$ (Fig. 2b, c and d). The time-course of the mRNA induction was similar for pulsed and continuous treatments whichever gene was tested. A maximal stimulation was observed after $12 \mathrm{~h}$ for cathepsin $\mathrm{D}$ and PR reaching values $2 \cdot 6-$ and $3 \cdot 5$-fold higher than controls; repeated administration on 2 successive days (restimulation experiment as in Fig. 1b) did not increase the effect above that of a single stimulation when data at $24 \mathrm{~h}$ and $48 \mathrm{~h}$ were considered (not shown). For pS2 mRNA, inductions were almost constant from $12-48 \mathrm{~h}(7 \cdot 8-$ to $11 \cdot 2$-fold) and increased slightly at $48 \mathrm{~h}$ when treatments were repeated on 2 successive days (not shown). Statistical analysis demonstrated no significant differences between pulsed and continuous exposures.

\section{Normal human breast cell proliferation}

A time-course study over a 7-day period of treatment showed that the growth of estradioltreated as well as control HBE cells was regular although proliferation of control cells tended to reach a plateau on days 6 and 7 (Fig. 3). Pulsed treatment or sustained incubation with estradiol led to a greater proliferation of $\mathrm{HBE}$ cells than control treatment on every day of the study (Fig. 3) in primary cultures from five different patients. This effect was statistically significant on days 4, 5 and 7 for the pulsed incubation and on days 2, 3, 4 and 7 for the continuous incubation in comparison with incubation without estradiol. Final statistical analysis did not include data obtained on day 6 since some measurements were missing from that day.

There was no significant difference between the two modes of estradiol treatment although the proliferation of cells submitted to pulsed estradiol stimulation tended to be slightly lower than that of cells receiving estradiol continuously on any day of the study.

Cellular estradiol retention was studied after a pulsed incubation ( $24 \mathrm{nM}$ for $1 \mathrm{~h}$ ) with a radioactive ligand. High transient intracellular estradiol levels were observed during the early incubation period and the amount of hormone rapidly decreased thereafter as indicated by the following values of $162 \pm 27,193 \pm 40,197 \pm 60,32 \pm 11$, $20 \pm 5$ and $17 \pm 10$ (means \pm s.E.M.) fmol $/ \mu \mathrm{g}$ DNA at $10 \mathrm{~min}, 30 \mathrm{~min}, 1 \mathrm{~h}, 2 \mathrm{~h}, 8 \mathrm{~h}$ and $24 \mathrm{~h}$ after the beginning of the pulse incubation respectively. Intracellular estradiol accounted for $89-75 \%$ of the total intracellular radioactivity from $10 \mathrm{~min}$ to $24 \mathrm{~h}$ respectively.

\section{Breast cancer cell proliferation}

Estradiol had a minimal effect at any dose on ER - cell lines whatever treatment was applied (Fig. 4d, e and f). In the three ER+ cell lines and after 7 days of treatment, there was a significant increase $(P<0 \cdot 0001$ for all groups except the group with continuous treatment for ZR 75-1 cells which was $P<0 \cdot 0004)$ in the proliferation of cells treated with a 1-h pulse or a 24-h continuous addition compared with control cells (Fig. 4a, b and c). Maximal mean stimulation was different between cell lines and reached 3.5- to 10-fold over control for T47D, MCF7 and ZR 75-1 (Fig. 4). The increase in proliferation was dose-dependent and soon reached a maximum in the MCF7 cell line whereas only the two final concentrations were plateauing in the two other ER+ cell lines (Fig. 4a, $\mathrm{b}$ and $\mathrm{c})$. 

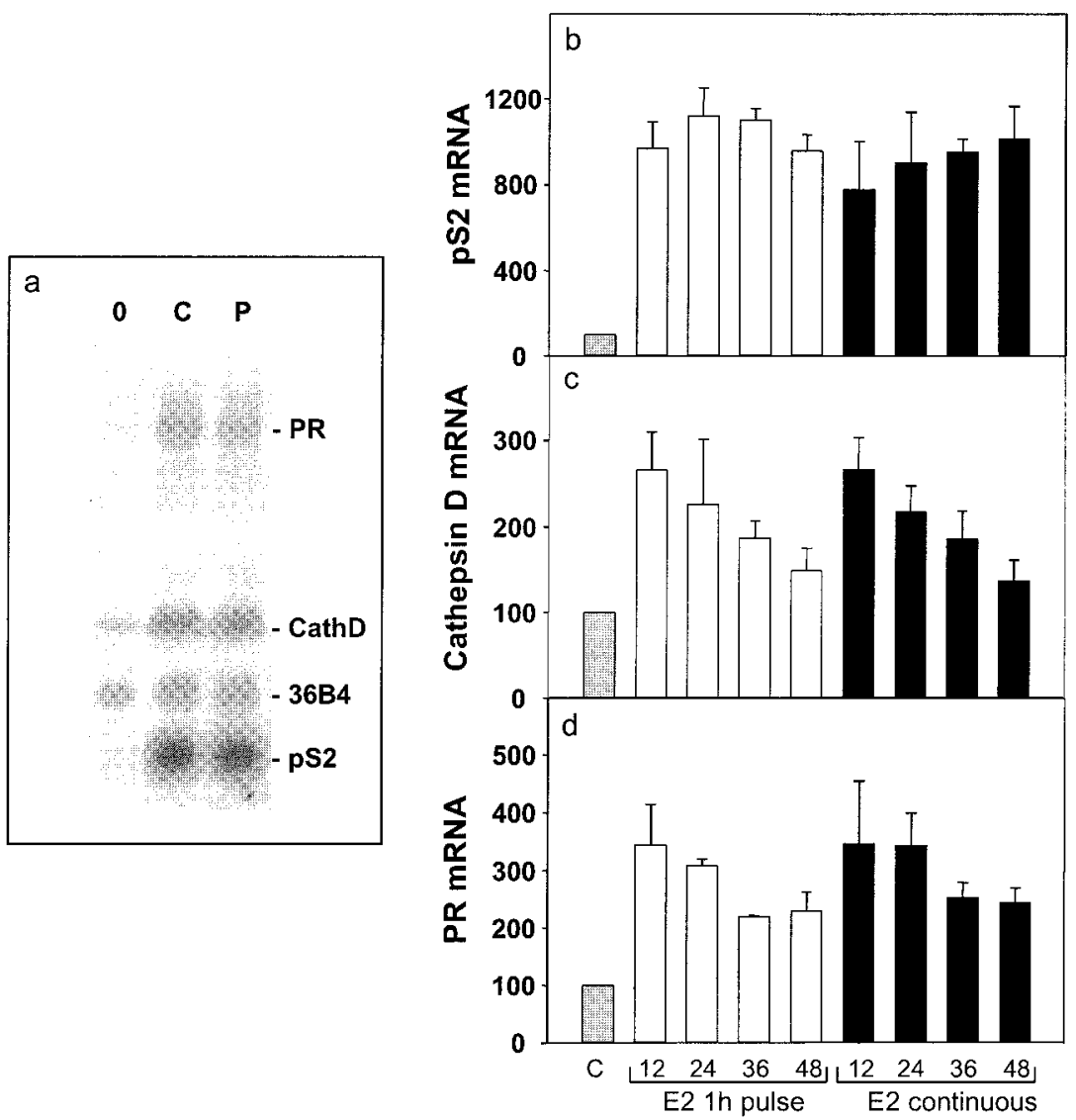

Figure 2 Regulation of mRNA expression after pulsed or continuous treatment with estradiol (E2). (a) Autoradiogram showing the detection by Northern blot of PR, cathepsin D (CathD), pS2 and 36B4 mRNAs after a single 1-h pulsed stimulation with estradiol at $7 \mathrm{nM}(\mathrm{P})$ or 24-h continuous treatment at $0.29 \mathrm{nM}(\mathrm{C})$. Basal levels $(0)$ represent the level of gene expression in control cells treated with vehicle. (b, $c, d)$ The three mRNAs levels were quantified as described in Materials and Methods after 12, 24, 36 or $48 \mathrm{~h}$ of pulsed (open bars) or continuous treatment (solid bars). Results are expressed as \% of control cells (C; grey bars) and included three independent experiments. Values are means \pm S.D.

As demonstrated in Fig. 4, statistical analysis on data from three experiments run in triplicate showed no overall significant difference between the pulsed and the continuous treatment in all three responsive ER + cell lines. In addition, since estrone is the main estradiol metabolite (reaching a $1 / 1$ estrone/estradiol ratio for the nasal and transdermal route and a 4/1 estrone/estradiol ratio for the oral route (Devissaguet et al. 1999)), we have evaluated the influence of estrone addition at a $4 \times$ concentration over estradiol in continuous treatment in another series of experiments and found no substantial effect of estrone on estradiol proliferative activity in the $\mathrm{ER}+$ cell lines (not shown).

\section{Discussion}

To date, estrogen replacement therapy has been mainly dedicated to provide sustained moderate plasma estradiol levels over $24 \mathrm{~h}$ as observed with reference formulations such as tablets and patches. Recently a nasal spray of estradiol has been developed. It displays completely different pharmacokinetics of plasma estradiol levels (Devissaguet 


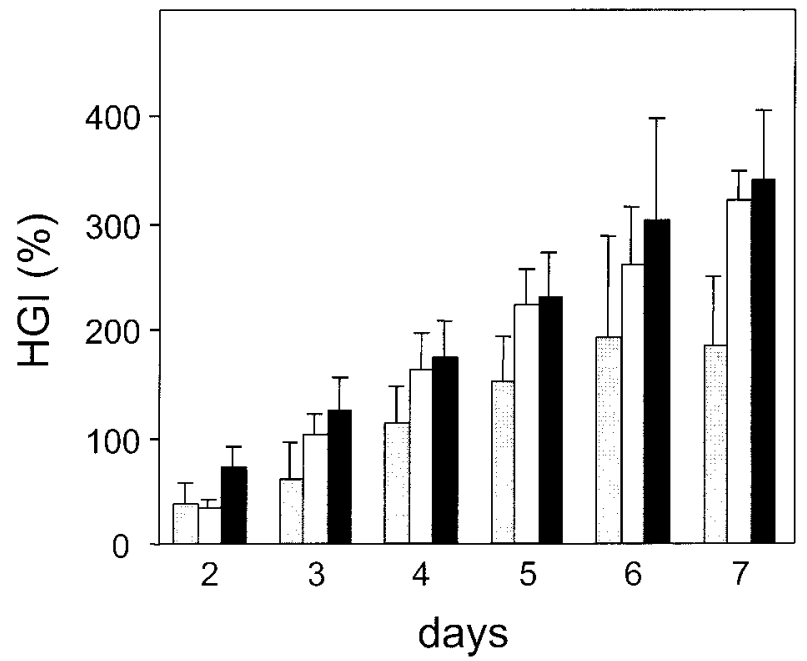

Figure 3 Proliferative effects of estradiol (E2) on normal human breast cells. Cells were stimulated by a pulse of $24 \mathrm{nM}$ estradiol for $1 \mathrm{~h}$ (open bars) and with continuous $1 \mathrm{nM}$ estradiol (solid bars) for $24 \mathrm{~h}$ for a treatment period of 7 days. Control cells (grey bars) received no hormone. Proliferation was measured every day using a histomorphometric method. Results are expressed as $\mathrm{HGl}$ and represent the means \pm S.E.M. of five experiments in which each sample was run in triplicate.

et al. 1999), leading to a transient exposure to high estradiol levels and introducing the new concept of pulsed estrogen therapy. In clinical trials, pulsed estrogen therapy has demonstrated a clinical efficacy similar to reference compounds on climacteric symptoms (Studd et al. 1999, Lopes et al. 2000) and bone (Garnero et al. 1999) and has been shown to be safe on some estradiol target organs (Mattsson et al. 2000), especially the endometrium (Gompel et al. 2000).

To provide further support for the efficacy and safety of such pulsed estrogen replacement therapy, we have compared, using human in vitro models, the results of a similar 24-h exposure to estradiol (equivalent area under the curve over $24 \mathrm{~h}$ ) with two different schemes of estradiol treatment mimicking nasal and oral hormone replacement administration. There are, in fact, no reports in the literature on the influence of time, and particularly of intermittent exposure to estradiol, on the biological effects of the estrogen. Most in vitro studies have been performed with continuous hormone incubation and were designed to evaluate concentration-related effects. We decided to analyze, in human breast cells, two hormone-sensitive cellular endpoints which are well studied, i.e. transcriptional activity and cell proliferation. The effect of estradiol on gene transcription is the major primary direct effect of the hormone acting via its receptors whereas mitogenic stimulation is a more delayed and complex process probably involving direct and indirect genomic action as well as non-genomic effects of estrogens (Pietras \& Szego 1999).

When studied up to $48 \mathrm{~h}$, our in vitro experiments allowed us to conclude that the same exposure of the cells to estradiol over $24 \mathrm{~h}$, performed either continuously or as a pulse of $1 \mathrm{~h}$, leads to the same estrogen-specific genomic effects. This also holds true for the expression of three representative hormone-regulated endogenous mRNAs analyzed by Northern blotting (pS2, cathepsin $\mathrm{D}$ and PR). These mRNAs are among the first characterized estradiol-induced human genes and considered either as good (PR and pS2) or bad (cathepsin D) pronostic markers in breast cancer. Previous work published by our laboratory and others has described the time-course of estradiol induction of pS2, cathepsin D and PR mRNAs in MCF7 cells (Westley et al. 1984, May et al. 1989, Rochefort 1995). In these former studies, estradiol stimulation was performed continuously at high doses (10 nM) and all three mRNAs inductions were sustained for at least $48 \mathrm{~h}$. In the present study, gene activation by estradiol was sustained at a high level for $\mathrm{pS} 2$ between 12 and $48 \mathrm{~h}$ (only small variations were noticed during the study period) whereas, for cathepsin D and PR, a decrease in mRNA synthesis was observed from $36 \mathrm{~h}$, the highest activation being at $12 \mathrm{~h}$. This might reflect structural differences of these two genes at the promoter level, generating variations in the affinity (or dissociation kinetics) of ER for their corresponding EREs. The same results concerning pulsed and continuous stimulations were obtained for the transiently transfected reporter construct containing an ERE which is widely used to allow the assessment of ER transcriptional activity in a simplified context (Demirpence et al. 1992, Gronemeyer \& Laudet 1995).

In the present study, we have also compared the effects of pulsed or continuous estradiol treatment on the proliferation of normal human breast epithelial cells and of human breast cancer cells. Normal human breast cell cultures provide a pertinent experimental model (Gompel et al. 

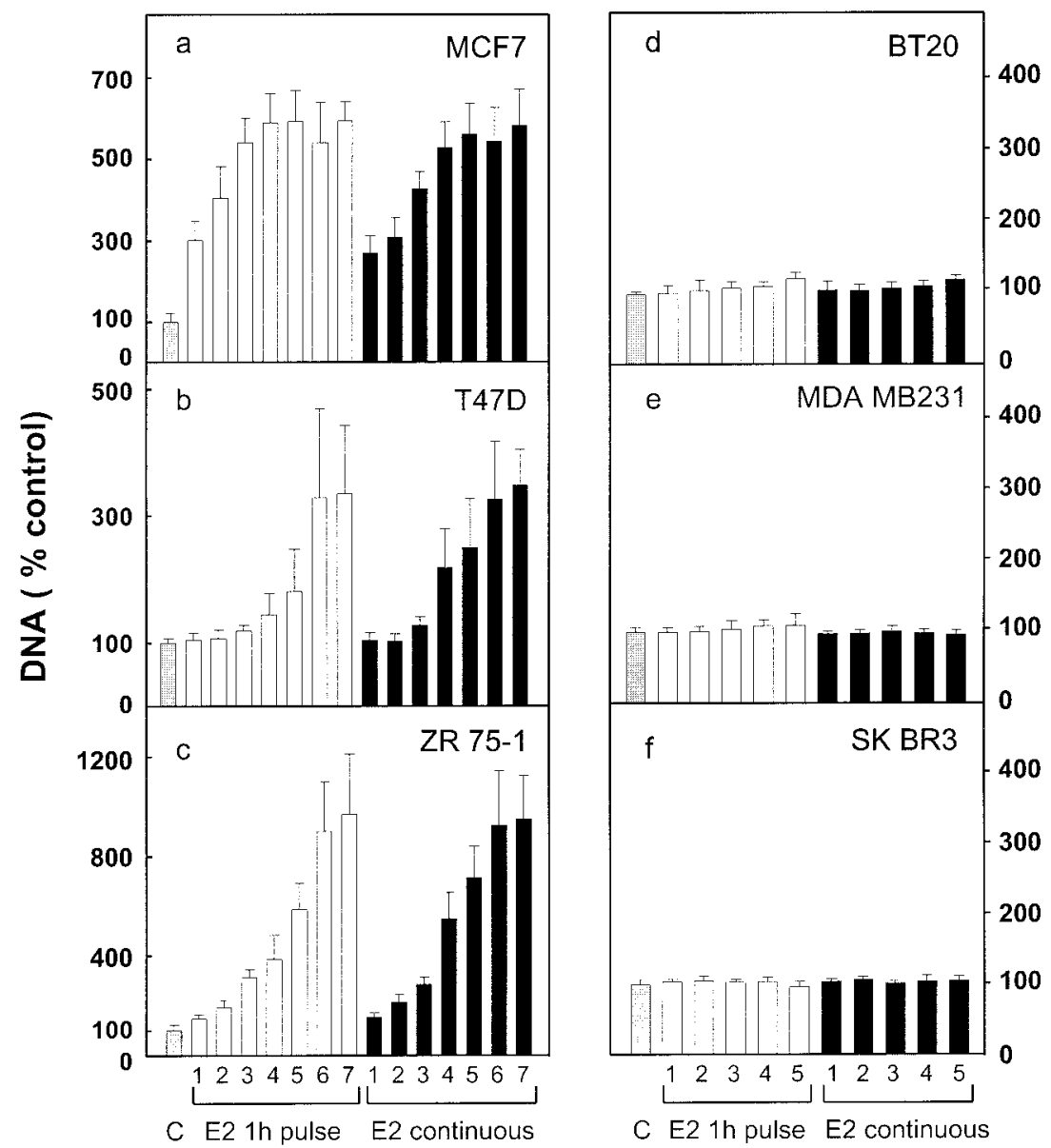

Figure 4 Proliferative effects of estradiol (E2) on ER+ and ER-human breast cancer cell lines. (a, b, c) Three ER+ cell lines were treated for 1-h pulses (open bars) with 0.007 (1), 0.035 (2), 0.07 (3), 0.35 (4), 0.7 (5), 7 (6) to 70 (7) $\mathrm{nM}$ estradiol or stimulated continuously (solid bars) with 0.00029 (1), 0.00145 (2), 0.0029 (3), 0.0145 (4), 0.029 (5), 0.29 (6) to 2.9 (7) nM estradiol for 7 days and total DNA was assayed in triplicate for each concentration tested and referred to control untreated cells (grey bars). Results represent the means \pm S.D. of three independent experiments. (d, e, f) Three ER-cell lines were similarly treated with 1-h pulses of estradiol (open bars) $(0.7$ (1), 7 (2), 70 (3), 700 (4) to 7000 (5) nM) or continuous estradiol (solid bars) (0.029 (1), 0.29 (2), 2.9 (3), 29 (4) to 290 (5) nM). Results represent the means \pm S.D. of three independent experiments.

1986) to predict breast carcinogenic risks, since proliferation is a major mechanism in the occurrence of breast cancer involving estrogens (IARG 1999). Since it might be claimed that experimental models for cancer behave differently from normal breast cells in various aspects, we decided that it was necessary to experiment on both hormone-sensitive models. However, normal human breast cells are difficult to cultivate and to handle and this represents a limiting factor for the performance of extensive studies. By contrast, human breast cancer cell lines are more convenient to work with and their biology is therefore better characterized, which justifies their wider use and renders comparisons easier between experiments.

While normal breast cells proliferated regularly over the 7-day study period, proliferation was greater in the presence of estradiol and there was no difference in the proliferation of cells receiving a 
pulsed treatment compared with cells receiving a continuous treatment. The highest significant difference between estradiol-treated cells (pulsed and continuous) compared with untreated controls was obtained on day 7 . In the six breast cancer cell lines examined, we confirmed that the growth of ER - cells remained poorly responsive, whereas the proliferation of the three ER+ cell lines was dramatically stimulated by the addition of estradiol as a 1-h pulse or in continuous treatment. The effects of estradiol on breast cancer cell proliferation were concentration dependent and our results are in agreement with the dose-response effects reported in the literature (Lippman et al. 1976). Moreover, as observed in normal cells, the stimulatory effects of a pulsed or a continuous treatment were similar at all concentrations assayed when cells received the same 24-h hormonal exposure (concentration $\times$ time). However, the degree of overall estrogenic stimulation and the profiles of the dose-response curves were somewhat different among those three models. The concentrations of ER $\alpha$ are very similar in the three lines (data not shown) and there is no evidence in the literature for a difference in the affinity of ER for estradiol in those cells which could simply explain such differences in the degree of response. These data might therefore reflect either different contributions of non-genomic effects (Pietras \& Szego 1999) or be the result of distinct interactions between intracellular regulatory pathways within cell lines. For example, synergisms between the ER and the tyrosine kinase transmembrane receptor pathways are important and cell and/or gene specific (Vignon et al. 1987, Ignar-Trowbridge et al. 1992, Kato et al. 1995, Migliaccio et al. 1996). If the basal growth level is high, as in MCF7 cells (in which insulin-like growth factors are potent mitogens), a minimal concentration of estradiol might be sufficient to synergize to reach an optimal growth rate, whereas higher concentrations are needed in T47D or ZR 75-1 cells which are much less sensitive to those factors and have a lower basal growth rate.

The present results have demonstrated that a pulsed incubation could produce, on gene expression and cell proliferation, the same effects as a continuous incubation, both in their extent and duration. This is in agreement with the results of Otto (1995) who has demonstrated that a pulse of estradiol as short as $1 \mathrm{~min}$ is sufficient to ensure the expression of the PR gene and cell proliferation in the MCF7 cell line. In addition, our data indicated that the two types of treatments are equivalent, on condition that the same exposure is provided in the experimental system; effects were similar although concentrations (high versus a low level) and incubation periods (short versus long) were different. Marth and Daxenbichler (1985) have similarly underlined the importance of the time to hormone exposure on the proliferation of breast cancer cells in experiments where time and concentrations were modulated. They suggested that the ER was a sensor measuring the time of estradiol exposure in a linear manner; proliferation could thus be predicted by the sum of pulses to which the cells would be exposed.

A continuous incubation was therefore not a requirement for sustained activity but, to achieve the same effects on the described endpoints, a short incubation needed higher concentrations as highlighted by the dose-response proliferation study. An important parameter to consider is hormone retention in both types of treatment. As shown by the cell retention study performed in human normal breast cells, pulsed incubation with high estradiol levels leads subsequently to transient high levels of total intracellular estradiol. This is in agreement with the passive diffusion of estradiol through cell membranes, which is influenced by the concentration gradient. However, an important point is the concentration of the remaining nuclear ER-bound hormone following the pulsed administration. Several parameters, such as variations in ER levels or deactivation signals, must also be taken into account. In response to estrogenic stimulation, $\mathrm{ER} \alpha$ expression is regulated both by transcriptional and post-transcriptional mechanisms (Saceda et al. 1988). More recently, post-translational control involving proteasomemediated degradation of the receptor upon estrogen treatment has also been demonstrated and appears to be linked to transcriptional activation (Lonard et al. 2000, Wijayaratne \& McDonnell 2001). In addition, the association of liganded ER with DNA (Shang et al. 2000) or coactivators (Stenoien et al. 2001) appears to be highly dynamic and the stability of the ER:estradiol complex could be influenced by the interaction with coactivators (Gee et al. 1999). Other parameters could also participate in the modulation of ER availability and nuclear distribution, complex stability or ligand 
dissociation rate and further studies are required to address some of these aspects in response to the two different modes of treatment.

Altogether, the data described herein demonstrate a similar efficacy of a brief estrogen incubation by comparison with sustained incubation on genomic and proliferative responses, thus further validating the concept of pulsed estrogen therapy.

\section{Acknowledgements}

We are grateful to Fanjaniriana Rabenoelina, Marcella Siromachkova and Christine Prebois for their contribution to this work and to Jean-Yves Cance for his help in preparing the illustrations. We thank Professor M Mimoun for providing the samples for normal breast cultures. We acknowledge Professor J P Daurès for his statistical expertise on breast cancer cell line experiments. We also thank members of Inserm units 339 and 540 and Institut de Recherches International Servier (IRIS) unit of Endocrinology and Rheumatology for discussions and comments on this research. This work was funded by Inserm and IRIS, Paris, France.

\section{References}

Cavailles V, Garcia M \& Rochefort H 1989 Regulation of cathepsin-D and pS2 gene expression by growth factors in MCF7 human breast cancer cells. Molecular Endocrinology 3 $552-558$.

Demirpence E, Pons M, Balaguer P \& Gagne D 1992 Study of an antiestrogenic effect of retinoic acid in MCF-7 cells. Biochemical and Biophysical Research Communications 183 100-106.

Devissaguet JP, Brion N, Lhote O \& Deloffre P 1999 Pulsed estrogen therapy: pharmacokinetics of intranasal 17-beta-estradiol (S21400) in postmenopausal women and comparison with oral and transdermal formulations. European Fournal of Drug Metabolism and Pharmacokinetics 24 265-271.

Garnero P, Tsouderos Y, Marton I, Pelissier C, Varin C \& Delmas PD 1999 Effects of intranasal 17 beta-estradiol on bone turnover and serum insulin-like growth factor I in postmenopausal women. Fournal of Clinical Endocrinology and Metabolism 84 2390-2397.

Gee AC, Carlson KE, Martini PG, Katzenellenbogen BS \& Katzenellenbogen JA 1999 Coactivator peptides have a differential stabilizing effect on the binding of estrogens and antiestrogens with the estrogen receptor. Molecular Endocrinology 13 $1912-1923$

Gompel A, Malet C, Spritzer P, Lalardrie JP, Kuttenn F \& Mauvais-Jarvis P 1986 Progestin effect on cell proliferation and 17 beta-hydroxysteroid dehydrogenase activity in normal human breast cells in culture. Fournal of Clinical Endocrinology and Metabolism $631174-1180$.
Gompel A, Bergeron C, Jondet M, Dhont M, Van der Mooren MJ, Toth KS, Panay N \& Von Holst T 2000 Endometrial safety and tolerability of AERODIOL ${ }^{\circledR}$ (intranasal estradiol) for 1 year. Maturitas 36 209-215.

Gronemeyer H \& Laudet V 1995 Transcription factors 3: nuclear receptors. Protein Profile 2 1173-1308.

Hussain AA 1998 Intranasal drug delivery. Advances in Drug Delivery Review 29 39-49.

IARC 1999 Hormonal contraception and post-menopausal hormonal therapy. In IARC Monographs on the Evaluation of the Carcinogenic Risks to Humans, vol 72, pp 485-490. Ed IARC. Lyon, France: IARC Press.

Ignar-Trowbridge DM, Nelson KG, Bidwell MC, Curtis SW, Washburn TF, McLachlan JA \& Korach KS 1992 Coupling of dual signaling pathways: epidermal growth factor action involves the estrogen receptor. PNAS 89 4658-4662.

Kastner P, Krust A, Turcotte B, Stropp U, Tora L, Gronemeyer H \& Chambon P 1990 Two distinct estrogen-regulated promoters generate transcripts encoding the two functionally different human progesterone receptor forms A and B. EMBO fournal 9 $1603-1614$

Kato S, Sasaki H, Suzawa M, Masushige S, Tora L, Chambon P \& Gronemeyer H 1995 Widely spaced, directly repeated PuGGTCA elements act as promiscuous enhancers for different classes of nuclear receptors. Molecular and Cellular Biology 15 5858-5867.

Lievertz RW 1987 Pharmacology and pharmacokinetics of estrogens. American Fournal of Obstetrics and Gynecology 156 1289-1293.

Lippman M, Bolan G \& Huff K 1976 The effects of androgens and antiandrogens on hormone-responsive human breast cancer in long-term tissue culture. Cancer Research 36 4610-4618.

Lonard DM, Nawaz Z, Smith CL \& O'Malley BW 2000 The 26S proteasome is required for estrogen receptor-alpha and coactivator turnover and for efficient estrogen receptor-alpha transactivation. Molecular Cell 5 939-948.

Lopes P, Merkus HM, Nauman J, Bruschi F, Foidart JM \& Calaf J 2000 Randomized comparison of intranasal and transdermal estradiol. Obstetrics and Gynecology 96 906-912.

Marth C \& Daxenbichler G 1985 Pulsatile versus continuous estradiol exposure in inducing proliferation of cultured ZR-75·1 human breast cancer cells. Fournal of Steroid Biochemistry 23 $567-572$.

Mattsson LA, Christiansen C, Colau JC, Palacios S, Kenemans P, Bergeron C, Chevallier O, Von Holst T \& Gangar K 2000 Clinical equivalence of intranasal and oral 17 beta-estradiol for postmenopausal symptoms. American Fournal of Obstetrics and Gynecology $182545-552$.

May FE, Johnson MD, Wiseman LR, Wakeling AE, Kastner P \& Westley BR 1989 Regulation of progesterone receptor mRNA by estradiol and antioestrogens in breast cancer cell lines. Fournal of Steroid Biochemistry 33 1035-1041.

Migliaccio A, Di Domenico M, Castoria G, de Falco A, Bontempo P, Nola E \& Auricchio F 1996 Tyrosine kinase/p21 ras/MAPkinase pathway activation by estradiol-receptor complex in MCF-7 cells. EMBO Foumal 15 1292-1300.

Otto AM 1995 A one minute pulse of estradiol to MCF-7 breast cancer cells changes estrogen receptor binding properties and commits cells to induce estrogenic responses. Fournal of Steroid Biochemistry and Molecular Biology 54 39-46.

Pietras RJ \& Szego CM 1999 Cell membrane estrogen receptors resurface. Nature Medicine 51330.

Prudhomme JF, Malet C, Gompel A, Lalardrie JP, Ochoa C, Boue A, Mauvais-Jarvis P \& Kuttenn F 198417 beta-Hydroxysteroid dehydrogenase activity in human breast epithelial cell and fibroblast cultures. Endocrinology 114 1483-1489.

Rochefort H 1995 Oestrogen- and anti-oestrogen-regulated genes in human breast cancer. Ciba Foundation Symposium 191 $254-265$. 
Saceda M, Lippman ME, Chambon P, Lindsey RL, Ponglikitmongkol M, Puente M \& Martin MB 1988 Regulation of the estrogen receptor in MCF-7 cells by estradiol. Molecular Endocrinology 2 1157-1162.

Shang Y, Hu X, DiRenzo J, Lazar MA \& Brown M 2000 Cofactor dynamics and sufficiency in estrogen receptor-regulated transcription. Cell 103 843-852.

Stenoien DL, Patel K, Mancini MG, Dutertre M, Smith CL, O'Malley BW \& Mancini MA 2001 FRAP reveals that mobility of oestrogen receptor-alpha is ligand- and proteasome-dependent. Nature Cell Biology 3 15-23.

Studd J, Pornel B, Marton I, Bringer J, Varin C, Tsouderos Y \& Christiansen C 1999 Efficacy and acceptability of intranasal 17 beta-oestradiol for menopausal symptoms: randomised doseresponse study. Aerodiol Study Group. Lancet 353 1574-1578.

Thenot S, Charpin M, Bonnet S \& Cavailles V 1999 Estrogen receptor cofactors expression in breast and endometrial human cancer cells. Molecular and Cellular Endocrinology 156 85-93.

Vignon F, Terqui M, Westley B, Derocq D \& Rochefort H 1980 Effects of plasma estrogen sulfates in mammary cancer cells. Endocrinology 106 1079-1086.
Vignon F, Bouton MM \& Rochefort H 1987 Antiestrogens inhibit the mitogenic effect of growth factors on breast cancer cells in the total absence of estrogens. Biochemical and Biophysical Research Communications 146 1502-1508.

Vignon F, Prebois C \& Rochefort H 1992 Inhibition of breast cancer growth by suramin. Fournal of the National Cancer Institute $\mathbf{8 4}$ 38-42.

Westley B, May FE, Brown AM, Krust A, Chambon P, Lippman ME \& Rochefort H 1984 Effects of antiestrogens on the estrogen-regulated pS2 RNA and the 52- and 160-kilodalton proteins in MCF7 cells and two tamoxifen-resistant sublines. Fournal of Biological Chemistry 259 10030-10035.

Wijayaratne AL \& McDonnell DP 2001 The human estrogen receptor-alpha is a ubiquitinated protein whose stability is affected differentially by agonists, antagonists, and selective estrogen receptor modulators. Fournal of Biological Chemistry 276 35684-35692.

Received 20 December 2001 Accepted 6 February 2002 